\title{
Eckart Otto's contributions to Pentateuchal research
}

Author:
Thomas C. Römer,2
Affiliation:
'College de France, Lausanne,
Switzerland
2Department of Old
Testament and Hebrew
Scriptures, University of
Pretoria, Pretoria,
South Africa
Corresponding author:
Thomas Römer,
thomas.romer1312@
gmail.com
Dates:
Romart phone or
Received: 30 Oct. 2018
Accepted: 22 Aug. 2019
Published: 12 Dec. 2019
to read online.
How to cite this article:
Römer, T.C., 2019, 'Eckart
Otto's contributions to
Pentateuchal research',
Verbum et Ecclesia 40 (1),
a1943. https://doi.org/
10.4102/ve.v40i1.1943
Copyright:
C 2019. The Authors.
Licensee: AOSIS. This work
is licensed under the
Creative Commons
Attribution License.

In order to highlight and appreciate Eckart Otto's contributions to a better scientific understanding of the Pentateuch, I will not enumerate and comment on all the books and papers that he has written in this regard because of space constraints in this article. I will proceed in a different way and start by summarising of what has happened in Pentateuchal research in Europe in the last 40 years. At the same time, I will try to show that Otto played a major role in these changes.

Intradisciplinary and/or interdisciplinary implications: This article gives an overview of Pentateuchal research in Europe over the last 40 years, with specific emphasis on the role that the German Old Testament scholar Eckart Otto played in these developments.

Keywords: Pentateuch; Hexateuch; Eckart Otto; Deuteronomy; Assyria and the Bible; Moses; Exodus.

\section{The reference of Documentary Hypothesis challenged}

The traditional Documentary Hypothesis that had dominated Pentateuchal research since the time of Wellhausen had a major triumph when Von Rad reformulated it and made the Yahwist (J) Israel's first and the greatest theologian. He located Junder Solomon and coined the idea of a Solomonic Enlightenment. Contrary to Wellhausen, Gunkel and many others, von Rad transforms the Yahwist into a personality who just had at his disposal what von Rad called the 'small theological credo' out of which he built the narrative of the Hexateuch (von Rad 1965). The Yahwist added the origins, Patriarchs, Sinai and wilderness traditions in order to provide the first narration of Yahweh's (YHWH) deeds for mankind and Israel.

\section{The challenges of 1975-1977}

In his essay about the structure of scientific revolutions, Thomas Kuhn challenged the then prevailing view of progress in 'normal science', (Khun 1996:5-6; 10; 24-32; 80), which was considered as 'development-by-accumulation', (Khun 1996:1-2) of accepted facts and theories. Kuhn (1996:52) argued for an episodic model in which periods of conceptual continuity are interrupted by periods of rejection of the traditional model. The discovery of 'anomalies' (Kuhn 1996: $62-64 ; 67 ; 82 ; 87 ; 113$ ) leads to new paradigms that ask new questions of old data, change the rules of the game and the so-called map directing new research. Something similar happened in the mid-1970s when three books appeared at the same time that radically challenged the traditional model of explanation of the formation of the Pentateuch, especially the two books, although published independently written by Rendtorff (1976) and Schmid (1976). ${ }^{1}$

\section{Yahwist and Deuteronomist}

Schmid (1976) observed that the so-called Yahwisthas was a very similar language as the Deuteronomist (D). Attributed to the Yahwist, Exodus 19:5 reads as follows: 'If you obey my voice and keep my covenant, you shall be my treasured possession out of all the people'. The same tone is observed in Deuteronomy 28:9, declaring 'If you listen to the voice of YHWH...', as well as Deuteronomy 7:6, asserting 'YHWH your God has chosen you out of all the peoples on earth to be his people, his treasured possession'. He concluded that the Yahwist must be quite close to the Deuteronomist and belong to the same theological or ideological group.

Martin Rose (1981) went a step further and compared parallel tradition in Deuteronomy and in Exodus and Numbers, traditionally attributed to J, as the spy story, the establishment of Judges and so on. He concluded that the Yahwist should be considered as later than the Deuteronomist and as a new prologue to the Deuteronomistic History.

1.See Der sogenannte Jahwist written by Schmid (1976) and Das Überlieferungsgeschichtliche Problem des Pentateuchs (English translation: The Problem of the Process of Transmission in the Pentateuch) written by Rendtorff (1976). 


\section{The abandonment of the Documentary Hypothesis}

The most radical challenge of the Documentary Hypothesis came from Rendtorff (1976) who questioned its validity. For Rendtorff, the end of the Yahwist simultaneously means the end of the Documentary Hypothesis. In a way, he goes back to Noth (1972) by modifying his fragmentary hypothesis (which Noth admitted for oral traditions only) which he combines with a supplementary hypothesis. He shows that most of the narrative traditions in the Pentateuch existed as independent stories before the later redactors combined them.

\section{Eckart Otto}

In a review article, Otto (1977) recognised the difficulty to go on with the traditional Documentary Hypothesis and pointed out that historical-critical research on the Hebrew Bible always had difficulties to coordinate different approaches, as the so-called Literarkritik (diachronic analysis) and the formcritical approach as well as the history of transmission of traditions. At the end of the review, he rightly states: "The Documentary hypothesis has to be challenged through new insights in the history of Israel and the Israelite religion'.

Otto's claim for a move from a purely literary analysis of the text to its embedding in social and religious history anticipates indeed the major changes in Pentateuchal research in the last 40 years to which he has massively contributed. As we see, Otto has taken up and elaborated, in his own way, the ideas (Rendtorff 1976; Schmid 1976).

\section{The importance of legal collections for our understanding of the formation of the Pentateuch}

Otto was perhaps the first scholar not only in the context of historical-critical research but also in the perspective of a comparative approach who recognised the importance of the three legal collections to understand the formation of the Torah. He was able to show how both the Covenant Code (Ex 20-23) and the Deuteronomic Code (Dt 12-16) were influenced by the Mesopotamian, especially Babylonian and Assyrian laws.

\section{The Covenant Code}

Otto (1988) showed how family law and the so-called casuistic law were originally transmitted in different contexts and later combined in the Covenant Code (Ex 20-23). He emphasised the importance of the understanding of traditional and state law for our understanding of the Israelite society and its transformation.

One year later, Otto (1989) wrote Rechtsgeschichte der Redaktionenim Kodex Ešnunna und im 'Bundesbuch': Eineredaktionsgeschichtliche und rechtsvergleichende Studiezualt babylonischen und altisraelitischen Rechtsüberlieferungen. This quite revolutionary book showed that the method of redactional criticism could be used not only for the biblical laws but also for the Mesopotamian law. He also showed intriguing similarities in the formation of the Codex Eshnunna and the Covenant Code.

Otto also demonstrated that the Codex Eshnunna and the Covenant Code are no 'legal codes' or civil law codes in the modern sense, nor are they learned speculations. They are 'manuals' (Lehrbücher), the aim of which is to train judges for their legal decisions, especially by way of conclusion by analogy.

\section{The Deuteronomic Code}

Otto's (1999a) most important contribution to Pentateuchal research is probably his book Das Deuteronomium. Politische Theologie und Rechtsreform in Juda und Assyrien. In this seminal work, Otto (1999a) showed how the first edition of Deuteronomy was directly influenced by the Assyrian Vassal Treaty terminology, and especially by the Loyalty oath of Essarhaddon from 672 BCE. The authors of the first edition of Deuteronomy took over passages from this treaty to construct their scroll as a Vassal Treaty between YHWH and Israel.

The Assyrian Loyalty Oath focuses on the recognition by the vassal kings of Assurbanipal as the legitimate successor of Esarhaddon and opens with a list of divine witnesses. The following stipulations of loyalty insist on the 'love' for Assurbanipal and the necessity to keep the commandments for future generations (Parpola, Watanabe \& Reade 1998):

(266) You shall love Assurbanipal... king of Assyria, your lord, as yourself.

(195) You shall hearken to whatever he says and do whatever he commands, and you shall not seek any other king or other lord against him.

(283) This treaty ... you shall speak to your sons and grandsons, your seed and your seed's seed which shall be born in the future. (n.p.)

These stipulations are very close to Deuteronomy 6:4-7a, a text which is very often considered as the original opening of Deuteronomy:

Hear, Israel: Yahweh is our God, Yahweh is One. You shall love Yahweh your God with all your heart, with all your life and with all your might. Keep these words that I am commanding you today on your heart and teach them to your sons. (vv. 4-7a)

There is also a stipulation which warns against instigators of insurrection, which may have been the pattern for the injunctions of Deuteronomy 13. The same holds true for the curses in Deuteronomy 28, which are modelled according the curses in the Vassal Treaty of Essarhaddon.

There is almost no doubt then that the authors of the first edition had at their disposal a copy of this treaty. This idea of Otto has now found confirmation by the recent discoveries in Tell Tayinat of present southeastern Turkey where a copy of this treaty was found dispatched in the Temple (Lauinger 2012). One can therefore imagine the same situation for Jerusalem. Because the Vassal Treaty of Essarhaddoncan was 
dated to 672 , the date of the original edition of Deuteronomy at the time of King Josiah becomes almost a certainty.

The fact that the authors of Deuteronomy took over to Assyrian language and ideology can be understood in a subversive manner: They wanted to show indeed that Israel has one suzerain to whom it owes absolute loyalty, but this lord is not the Assyrian king but YHWH, God of Israel.

This link between the Deuteronomic Code and the Assyrian Vassal treaties, in my view, belongs to the most important discoveries in the Old Testament scholarship, and Otto has played a major role in this respect.

\section{The Holiness Code (Lv 17-26)}

In several publications, ${ }^{2}$ Otto has also contributed to a better understanding of Leviticus $17-26$ by showing that this is not an independent law code but a late post-priestly composition.

The so-called Holiness Code should be understood as an attempt to conciliate the Deuteronomistic law with the priestly prescriptions in Leviticus $1-16$ so that we have, as Otto pointed out, the beginning of interpretation and harmonisation of the different law codes already inside the Pentateuch.

The three law codes which Otto helped us to understand in a new and better way also reflect the three major historical contexts for the formation of the Pentateuchal text: the 8th century BCE, the end of the 7th century (the time of Josiah) and finally the Persian period.

We must be grateful to Otto for having pointed out the importance of these law codes, which, especially in Protestant exegesis, have very often been neglected.

\section{The question of the priestly document $(P)$ and its ending}

Most scholars would agree to locate P at the end of the socalled exilic (or rather Babylonian) period. There is, however, an important question to which Otto has contributed in an important way, namely, the question of the endpoint of the first P, the so-called Grundschrift (Pg) (Otto 1997).

A majority of scholars still follow Noth's (1972, 1st edn., 1981) view that Pg ended with the death of Moses in Deuteronomy 34:1*... 7-9 (Frevel 1999). Because Noth considered $\mathrm{P}$ as comprising all the major themes of the Pentateuch, it appeared quite logical that Pg would end with the death of Moses. However, there is no real evidence of priestly style in Deuteronomy and one may also ask whether the installation of Joshua as Moses' successor in Deuteronomy 34:8-9 constitutes an appropriate conclusion of a work; rather than concluding a story, these verses serve to introduce the Joshua and the conquest narrative.
An obvious question present itself: If Deuteronomy 34 does not contain the ending of $\mathrm{Pg}$, where would it be discovered?

Some scholars have opted to return to Wellhausen (1963) in a hope of including parts of the book of Joshua in the original P account (Bass 1985; Guillaume 2009; Lohfink 2005). According to this view, the end of Pg could be found in Joshua 18:1, 'the land ('eretz) lay subdued before them'. At first sight these words look like a fitting inclusion together with God's blessings and order in Genesis 1:28, 'be fruitful and multiply, and fill the earth ('eretz) and subdue it'. However, Genesis 1:28 is addressed to humanity in general, whereas Joshua 18:1 applies specifically to Israel. Even in P's conception, Genesis 1:28 apply to the 'perfect creation' in which man is originally a vegetarian; it is significant that the 'new deal' between God and mankind after the Flood no longer contains the command to subdue the earth.

If neither the end of Deuteronomy nor the end of Joshua offers an appropriate conclusion to $\mathrm{Pg}$, what about Numbers? As Otto and others have demonstrated, the so-called P-texts in Numbers are quite different from the P-texts in Genesis to Leviticus. The military idea of the people organised in a camp does not fit to the priestly theology in the first books of the Pentateuch. The only remaining possibility is that the original ending of $\mathrm{P}$ be found instead within the priestly account of Israel's sojourn at Mt Sinai. In fact, the Sinai revelation has often been recognised as the very centre and purpose of the priestly narrative. This suggestion has been adopted in recent years by a growing number of scholars, especially under the influence of Otto (and also Pola 1995). In his article Forschungenzur priesterschrift, Otto (1997) discussed new publications about the priestly texts and suggested that the end of the original P-stratum of the Pentateuch should be found in Exodus 27, in the divine commandment for the construction of the sanctuary. Although one may discuss whether this is the best option for the original conclusion of $\mathrm{P}$ or whether one should find this conclusion in the last chapter of Exodus, there is quite good evidence now that the construction of the sanctuary is the climax of the original P (Nihan 2007). As often observed, ${ }^{3}$ the conclusion of the building account of the Tabernacle in Exodus 39-40 contains several parallels with the priestly creation account in Genesis 1:1-2:3, and could be considered as an inclusio around the whole priestly narrative.

If $\mathrm{P}$ did only comprise the P-texts in Genesis to Exodus, to which were added later the first part of Leviticus, then $P$ is not the architect of the whole Pentateuch.

On the other hand, as Otto has emphasised, the priestly account of Exodus functions in the original P document as a kind of 'mortar' that holds together the creation story, the ancestors and the establishment of Israel's cult. This means that $\mathrm{P}$ is probably the first author (or redactor) who joined these three originally independent literary units.

3.See Buber \& Rosenzweig (1936), taken up by Blum (1990) and others. 
Priestly document also promotes an inclusive monotheism, with the theory of a three-step revelation of the divine name: Elohim: for all humans; El Shadday: for Abraham and his offspring (Gn 17) and $Y H W H$ : for Israel through Moses (Ex 6) (De Pury 2007).

This means that for P all human beings worship the same deity, although they call it by different names. The priestly monotheism can therefore be considered as an 'inclusive monotheism'.

\section{The relationship between priestly document and non-priestly document}

Traditionally, the non-P texts were labelled Yahwist and dated before P. Otto (1996a, 1996b) has shown, however, that the label non-P does not necessarily mean pre-P. In several publications, he has suggested that in some important narratives, especially in the creation and fall story, and the story of the call of Moses, the so-called J-texts might well be later than the $\mathrm{P}$ version.

I think Otto (1996b) is right to point out that in these and other texts there is an important number of passages that should probably be labelled post-P. This also means that we need to pay much more attention to what has traditionally been called 'last redactions' or 'final redactions'. Thanks to Otto (and others), it has become clear that those 'last redactions' are in fact constitutive for the formation of the Pentateuch.

\section{Hexateuch or Pentateuch}

The idea that there was an original Hexateuch and not a Pentateuch is as old as the Documentary Hypothesis. It rose because of the idea that the book of Joshua is the fitting conclusion to a narration that starts with the promise of the land in the book of Genesis so that the end of $\mathrm{J}$ and $\mathrm{E}$ (and also P) should be preserved in Joshua. The assumption of an 'old' Yahwistic Hexateuch (covering the stories from the origins to the entry into the land) seems nowadays very difficult to maintain because the texts in Genesis to Joshua that try to 'create' a Hexateuch are apparently late insertions. Genesis 50:25 and Exodus 13:19, which deal with the transportation of Joseph's bones from Egypt to Israel, would serve as such an example. These verses do not make much sense in the context of the Pentateuch. They do, however, serve as a preparation for Joshua 24. Joshua 24:32 is thus the end of a narrative trajectory that starts in Genesis 50:25 (or even in Gn 33:19).

The most decisive argument for the existence of a Hexateuch is Joshua 24 (Römer \& Brettler 2000). This final discourse is clearly later than Joshua's last words in Chapter 23. Joshua introduces his speech by the prophetic formula: "Thus says YHWH, the God of Israel' (v. 2), and appears to be a 'prophet like Moses' (Dt 18:15). At the end of the speech, he is more and more comparable to Moses. He concludes a covenant, gives the people statutes and ordinances and writes all 'these words' in the book of the law of God (sephertoratelohim) (v. 25 - 26). The expression haddebarimha'eleh may refer back to the beginning of the book of Deuteronomy: 'elehhaddebarim (according to Seidel's law ${ }^{4}$ ) and may be understood as an attempt to present the book of Joshua as inseparably linked to Deuteronomy. One way or another, the author of Joshua 24 who was writing in the Persian period wanted to create a Hexateuch. Therefore, Otto, Achenbach and others are right in distinguishing inside the Torah a 'Hexateuchal redaction' and a 'Pentateuchal redaction'.

According to this model, an important number of texts that were considered as 'Yahwistic' and 'Deuteronomistic' are now attributed to the Hexateuch or Pentateuch redactors. These two redactions apparently are in conflict with competing priestly and other groups. As Otto (2000) has rightly observed, the two options betray quite different ideas about what should be cardinal to Judaism: For the Hexateuch the main theme is the land, whereas for the Pentateuch Israel's identity is founded in the Torah mediated by Moses. That makes it quite understandable that the idea of a Hexateuch was rejected in favour of the Torah. The last words of the Deuteronomy, which quite obviously belong to the redactors of the Pentateuch, asserting that 'never since has arisen a prophet in Israel like Moses, whom YHWH knew face to face' (Dt 34:10), establish an important hiatus between Moses and the following books. Joshua 24 tries to present Joshua as a prophet and a 'second Moses', whereas Deuteronomy 34:10-12 states that Moses and Joshua cannot be put on the same level.

\section{Towards a new fragmentary hypothesis}

Putting together the different insights of Otto about the Pentateuch, it has become clear that one should adopt a revised 'fragmentary hypothesis', according to which P was the first to unite several independent narrative cycles and the Hexateuchal- and Pentateuchal redactors were the architects of the Torah. In this regard, it has also become obvious that most parts of the book of Numbers only arose at a very late stage of the formation of the Pentateuch (Achenbach 2003; Römer 2007). In my view, this new model offers a better explanation for the constitution of the Torah and allows explaining the formation of different parts of the Torah with different models.

\section{The book of Deuteronomy}

Let me finish my appreciation of Otto's work by highlighting his work on Deuteronomy, which has culminated in his commentary on that book. ${ }^{5}$ This commentary is such a compendium that it could probably never be replaced by

4.This law states that citation within a biblical text frequently reverses the source text. The original text $A B$ is then cited as $B A$.

5.See Otto's commentary Deutoronomium 1-11 (2012) and 12-26 (2016). 
other commentaries on Deuteronomy. It is one of the major contributions to Deuteronomy since that of De Wette (1806), and it will be considered a milestone in biblical scholarship during the 21st century.

\section{From De Wette to Otto}

In a lengthy footnote of his quite short 1805 dissertation, De Wette (1806) identified the book found during the restoration of the Jerusalemite Temple under King Josiah with the book of Deuteronomy. ${ }^{6}$ The identification was nothing new; however, the possibility that Deuteronomy could stem from the time of Josiah was new. It would have allowed dating the book of Deuteronomy precisely. With this dating of Deuteronomy, or its first edition, De Wette (1806) provided, as Eissfeldt (1965) put it, 'Pentateuchal criticism with a "point of Archimedes"' which allowed dating other books and texts according to their relation with Deuteronomy: before or after 621 BCE. Kuenen (1886) and Wellhausen (1963) built on that date, claiming that the Yahwist and the Elohist preceded D, whereas the Priestly Source was considered post-D. De Wette's (1806) insights provided a major beginning for the establishment of the Documentary Hypothesis; however, Deuteronomy itself somewhat disappeared from Pentateuchal research. It did not fit well in a hypothesis reconstructing parallel documents, which became something like a dogma in the beginning of the 20th century. This disappearance was almost total after Noth's (1991) invention of the 'Deuteronomistic History' because he considered that the Urdeuteronomium (which for him corresponded basically to Dt: 5-30) was revised by a Deuteronomist during the time of the Babylonian exile who transformed it into an introduction to the books of Joshua to Kings (Noth 1991). Consequently, Noth (1991) transformed the Pentateuch into a Tetrateuch, ratifying the difference between Deuteronomy and the other books and traditions of the Torah. And indeed, most monographs and articles devoted to the book of Deuteronomy dealt with it in the context of the Deuteronomistic History.

Even in the elaboration of new models for the formation of the Pentateuch, especially in European scholarship, which all the more challenges the traditional Documentary Hypothesis, Deuteronomy still plays a marginal role.

Otto's merit, amongst many others, is to have replaced Deuteronomy in the centre of Pentateuchal research, even suggesting that this book should be considered as the core of the Torah, as the scroll with which everything started (Otto 2009).

\section{Otto's commentary: Diachronic and synchronic readings}

Otto's commentary (2012) starts with a history of research, a book in itself, because it contains about 170 pages and is eminently readable and informative. He begins this history with de Spinoza (1951) and Simon (2008). Both abandon the idea that Moses was the author of the Pentateuch and focus on the edition of the Torah during the time of Ezra. This again shows that Otto (2004) wants to understand the book of Deuteronomy in the context of Pentateuchal research.

Deuteronomy plays a major role in Spinoza's demonstration that Moses cannot be the author of the Pentateuch because the book often speaks of him in the third person. It is, of course, impossible here to summarise this very agreeable and informative presentation of more than 300 years of critical investigation on Deuteronomy.

The fact that Otto (2012) concludes his survey with a chapter entitled 'On the Way to a Synchronic Interpretation' is also interesting. Otto's main point, which also appears very clearly in the structure of his commentary, is that one cannot and should not oppose synchronic and diachronic investigations of Deuteronomy. Because Otto thinks that a major part of the framework in Chapters 1-11 and 27-34 stems from the Persian period, synchronic and diachronic readings could be easily joined. In fact, a synchronic analysis could help us understand how the last redactors wanted the book to be read and understood.

I very much appreciate Otto's (2004) attempts to combine synchronic and diachronic analysis of the book. In each chapter, he offers a synchronic overview, a diachronic analysis, a very detailed commentary of the passage and finally a synchronic interpretation of the passage.

We have already discussed Otto's contribution of the reconstruction of the first edition of Deuteronomy and the importance of Neo-Assyrian treaties so that there is no necessity to come back to this point.

\section{The last redactions and the hermeneutics of Deuteronomy}

Perhaps the most important stage in the formation of Deuteronomy is its post-exilic integration in the Pentateuch which occurred following the competition between redactors who wanted to create a Hexateuch and those who favoured a Pentateuch. We have in this commentary as well as in his earlier work one of Otto's major contributions to the current debate about the formation of the Torah. Otto is inclined to attribute major parts of Deuteronomy to these late redactions, but he is also cautious enough to maintain the attribution of some passages to these redactions undecided.

Otto's comments about the book of Deuteronomy in the context of theology and hermeneutics of the Law in the Pentateuch are very helpful. He masterfully demonstrates how the last redactors understood the place of Deuteronomy after the divine law had been revealed through Moses on MountSinai. For the redactors of the Pentateuch, Deuteronomy was understood as an interpretation and actualisation of the Law given through Moses on Mount Sinai. This is already suggested in the introduction, Deuteronomy 1:1 - 5. It was revised by the last editors in the book who had in mind 
the Pentateuchal perspective of Deuteronomy. Otto is correct when he understands the $b-^{-}-r$ in Deuteronomy 1:5 as meaning 'to expound'.

Consequently, Moses, in the book of Deuteronomy, is constructed as a Schriftgelehrter, as a scribe who has authority to comment and to actualise the law. So we may ask, Otto and ourselves, whether this hermeneutical idea already prepares the later concept of a 'written' and an 'oral' Torah. By constructing Deuteronomy as situated 'between the times', to pick an expression that Otto uses quite often, the last redactions clearly identify the addressees of the book with the second generation of the wilderness, who find themselves between the Exodus and the conquest of the land. This also means then that the frequent mentions of the 'fathers' do not refer to the Patriarchs, but to the 'direct' fathers of the constructed audience, that is the generation of the Exodus.

\section{Conclusion}

I conclude by underlying the importance of Otto's work on the Pentateuch and especially on the book of Deuteronomy. His monumental commentary on Deuteronomy will remain an indispensable tool for every scholar working on Deuteronomy for a very long time. Otto has re-emphasised the importance of Deuteronomy for Pentateuch research.

Maybe Otto has achieved the last one-man commentary of such magnitude. Of course, research and scholarship will go on, but I wonder whether after 40 years (the time of the wilderness generation) someone will be able to give as informed a view as Otto did. It will be a difficult task.

\section{Acknowledgements Competing interests}

The author declares that they have no financial or personal relationships which may have inappropriately influenced them in writing this article.

\section{Author's contributions}

T.C.R. is the sole author of this research article.

\section{Ethical consideration}

This article followed all ethical standards for carrying out research without direct contact with human or animal subjects.

\section{Funding information}

This research received no specific grant from any funding agency in the public, commercial or not-for-profit sectors.

\section{Data availability statement}

Data are available from the author upon request.

\section{Disclaimer}

The views and opinions expressed in this article are those of the author and do not necessarily reflect the official policy or position of any affiliated agency of the author.

\section{References}

Achenbach, R., 2003, Die Vollendung der Tora: Studienzur Redaktionsgeschichte des Numeribuchesim Kontextvon Hexateuchund Pentateuch, Beihefte der Zeitschriftfüraltorientalischeundbiblische Rechtsgeschichte 3, Harrassowitz, Wiesbaden, Germany.

Seebass, H., 1985, 'Josua', Biblische Notizen 28(3), 53-65.

Blum, E., 1990, Studienzur Komposition des Pentateuch, BZAW 189, de Gruyter, Berlin.

Buber, M. \& Rosenzweig, F., 1936, Die Schriftundihre Verdeutschung, Schocken, Berlin, Germany.

De Pury, A., 2007, 'Pg as the absolute beginning', in T. Römer \& K. Schmid (eds.), Les dernières rédactions du Pentateuque, de l'Hexateuqueet de l'Ennéateuque, pp. 99-128, Peeters UniversityPress, Leuven.

De Spinoza, B., 1951, A theologico-political treatise and a political treatise (translated from Latin with an Introduction by R.H.M. Elwes), Dover Publications, New York, NY

De Wette, W.M.L., 1806, Dissertatiocritico-exegetica qua Deuteronomium a prioribus Pentateuchi Librisdiversum, aliuscuiusdamrecentiorisauctoris opus essemonstratur, G. Meimerum, Berlin, Germany.

Eissfeldt, O., 1965, The Old Testament: An introduction, Harper, San Fransisco, CA.

Frevel, C., 1999, Mit Blickaufdas land die Schöpfungerinnern. Zum ende der Priester grundschrift (HBSt 23), Herder, Freiburg, Germany.

Guillaume, P., 2009, Land and calendar: The priestly document from Genesis 1 to Joshua 18, T\&T Clark, New York.

Kuenen, A., 1886, A historical-critical inquiry into the origin and composition of the Hexateuch, Macmillan, London.

Kuhn, T., 1996, The Structure of Scientific Revolutions, 3rd edn., The University of Chicago Press, Chicago.

Lauinger, J., 2012, 'Esarhaddon's succession treaty at Tell Tayinat: Text and commentary', Journal of Cuneiform Studies 64(1), 87-123. https://doi.org/10.5615/jcunestud. 64.0087

Lohfink, N., 2005, 'Die Land übereignung in Numeri und das Ende der Priesterschrift: Zueinemrätselhaften Befundim Buch Numeri', in N. Lohfink (ed.), Studien zum Deuteronomium und zur Deuteronomistischen Literatur V, pp. 273-292, Katholisches Bibelwerk, Stuttgart, Germany.

Mathys, H.-P., 2008, 'Wilhelm Martin Leberechts de Wette's dissertatiocriticoexegeticavon 1805', in M. Kessler \& M. Walraff (eds.), Biblische theologie und historisches denken, wissenschaftsgeschichtliche studien, aus anlass der 50. Wiederkehr der basler promotion von rudolf smend, Studien zur Geschichte de Wissenschaften in Basel, Neue Folge, 5, pp. 171-211, Schwabe, Basel, Switzerland.

Nihan, C., 2007, Frompriestly Torah to Pentateuch: A study in the composition of the book of Leviticus (FAT II/25), Mohr Siebeck, Tübingen, Germany.

Noth, M., 1972, A history of Pentateuchal traditions, Prentice Hall, Ann Arbor, MI.

Noth, M., 1981, A history of Pentateuchal traditions, Scholars Press, Englewood Cliffs, $\mathrm{NJ}$, reprinted Atlanta, GA.

Noth, M., 1991, The Deuteronomistic history (JSOTSup 15), Sheffield Academic Press, Sheffield, UK.

Otto, E., 1977, 'Stehen wir vor einem umbruch in der pentateuchkritik?', Verkündigung und Forschung 22(1), 82-97. https://doi.org/10.14315/vf-1977-0106

Otto, E., 1988, Wandel der Rechtsbegründungen in der Gesellschaftsgeschichte des antiken Israel: Eine Rechtsgeschichte des 'Bundesbuches' Ex XX 22-XXIII, E.J. Brill, Leiden, the Netherlands.

Otto, E., 1989, Rechtsgeschichte der Redaktionenim Kodex Ešnunna und im 'Bundesbuch': Eineredaktionsgeschichtliche und rechtsvergleichende studiez ualt babylonischen und alt Israel itischen Rechtsüberlie ferungen, Universitäts Verlag/ Vandenhoeck \& Ruprecht, Göttingen, Germany.

Otto, E, 1994, 'Das Heiligkeitsgesetz Leviticus 17-26 in der Pentateuchredaktion', in P. Mommer \& W. Thiel (eds.), Altes testament - Forschung und wirkung: Festschrift für Henning Graf Reventlow, pp. 65-80, Peter Lang GmbH, Internationaler Verlag der Wissenschaften, Berlin, Germany.

Otto, E., 1996a, 'Die nachpriesterliche Pentateuch Redaktion im Buch exodus', in M. Vervenne (ed.), Studies in the book of Exodus: Redaction - Reception Interpretation, pp.61-11, Peeters University Press, Leuven, Belgium.

Otto, E., 1996b, 'Die Paradieserzählung Genesis 2-3: Eine nachpriesterliche Lehrerzählung in ihremreligions historischen kontext', in A.A. Diesel, R.G. Lehmann, E. Otto \& A. Wagner (eds.), 1996, Jedes Ding hat seine Zeit...": Studien zur Israelitischen und altorientalischen Weisheit. Diethelm Michel zum 65, Geburtstag, pp. 167-192, De Gruyter, Berlin, Germany.

Otto, E., 1997, 'Forschungen zur priesterschrift', Theologische Rundschau 62(1), 1-50.

Otto, E., 1999a, Das Deuteronomium. politische theologie und rechtsreform in Juda und Assyrien, De Gruyter, Berlin, Germany.

Otto, E., 1999b, 'innerbiblische Exegese im Heiligkeitsgesetz Levitikus 17-26', in H. Fabry \& H. Jüngling (eds.), Levitikusals Buch, pp. 125-196, Philo Verlag-Ges., Berlin, Germany. 
Otto, E., 2000, Das Deuteronomium im Pentateuch und Hexateuch. Studien zur literatur geschichtevon Pentateuch und Hexateuchim lichte des Deuteronomiums rahmen, Mohr Siebeck, Tübingen, Germany.

Otto, E., 2004, 'The Pentateuch in synchronic and diachronical perspectives: Protorabbini calscribal erudition mediating between Deuteronomy and the priestly code', E. Otto \& R. Achenbach (eds.), Das deuteronomium zwischen Pentateuch und Deuteronomistischem geschichtswerk (FRLANT 206), pp. 14-35,
und Vandenhoeck \& Ruprecht, Göttingen, Germany.

Otto, E., 2009, 'Deuteronomium und pentateuch', in Die tora: Studien zum Pentateuch (BZAR, 9), pp. 168-228, Harrassowitz, Wiesbaden, Germany.

Otto, E., 2012, Deutoronomium 1-11 (Herders theologischer kommentar zum alten testament), Herder, Freiburg, Germany.

Otto, E., 2016, Deuteronomium 12-34 (Herders theologischer kommentar zum alten testament), Herder, Freiburg, Germany.

Parpola, S., Watanabe, K. \& Reade, J. (eds.), 1988, Neo-Assyrian treaties and loyalty oaths, (n.p.), Helsinki University Press, Finland.

Pola, T., 1995, Die ursprüngliche Priesterschrift. Beobachtungen zur Literarkritik und Traditionsgeschichte von Pg (WMANT 70), Neukirchener, Neukirchen-Vluyn, Germany.
Rendtorff, R., 1976, Das überlieferungsgeschichtliche problem des Pentateuch, De Gruyter, Berlin, Germany.

Römer, T., 2007, 'Israel's sojourn in the wilderness and the construction of the book of numbers', in R. Rezetko, T. Lim \& B. Aucker (eds.), Reflection and refraction. Studies in Biblical historiography in honour of A. Graeme Auld (VT.S 113), pp. 419-445, Brill, Leiden, Boston, MA.

Römer, T. \& Brettler, M.Z., 2000, 'Deuteronomy 34 and the case for a Persian hexateuch', Journal of Biblical Literature 119(3), 401-419. https://doi.org/10.2307/3268406

Rose, M., 1981, Deuteronomist and Jahwist. Untersuchungen $z u$ den Berührungspunkten beider Literaturwerke (AThANT 67), TVZ, Zürich.

Schmid, H.H., 1976, Der sogenannte Jahwist: Beobachtungen und Fragenzur Pentateuchforschung, Theologischer, Zürich, Switzerland.

Simon, R., 2008, Histoire critique du Vieux testament (1678), Nouvelle édition annotée et introduite par Pierre Gibert, Bayard, Paris, France.

Von Rad, G., 1965, 'The form critical problem of the Hexateuch', in G. Von Rad (ed.), The problem of the Hexateuch and other essays, pp. 1-78, Oliver \& Boyd, Edinburgh, UK, reprinted 1984, SCM Press, London.

Wellhausen, J., 1963, Die Composition des Hexateuchsund der historischen Bücher des Alten testaments (1899), de Gruyter, Berlin, Germany. 